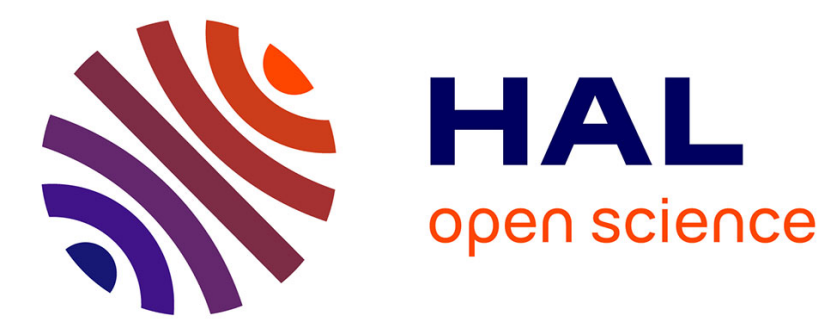

\title{
Tradition and Meaning: One Interpretation of Renaissance Theology in the Twentieth Century \\ Jean-Paul Rosaye
}

\section{To cite this version:}

Jean-Paul Rosaye. Tradition and Meaning: One Interpretation of Renaissance Theology in the Twentieth Century. Reformation and Renaissance Review, 1999, 2, pp.9-19. hal-00323004

\section{HAL Id: hal-00323004 \\ https://hal.science/hal-00323004}

Submitted on 19 Sep 2008

HAL is a multi-disciplinary open access archive for the deposit and dissemination of scientific research documents, whether they are published or not. The documents may come from teaching and research institutions in France or abroad, or from public or private research centers.
L'archive ouverte pluridisciplinaire HAL, est destinée au dépôt et à la diffusion de documents scientifiques de niveau recherche, publiés ou non, émanant des établissements d'enseignement et de recherche français ou étrangers, des laboratoires publics ou privés. 


\section{TRADITION AND MEANING: ONE INTERPRETATION OF RENAISSANCE THEOLOGY IN THE TWENTIETH CENTURY \\ Jean-Paul Rosaye \\ Université d'Artois}

The present article intends to look at Renaissance theology from the point of view of the historian of ideas. As a matter of fact, we cannot but adopt the perspective of the twentieth century whenever we deal with Renaissance theology: how far is our interpretation objective is a problem partaking not only in the nature of historical events but also in our ideological preferences. I shall therefore try to define first of all the general conditions in which history can be deemed objective before introducing T.S. Eliot's famous interpretation of Renaissance Anglicanism. How he came to be interested in it and how he evaluated it is not extremely revealing as far as Christian thought is concerned, it also expresses some tendencies in the history of ideas, literary, philosophical, and theological, in the twentieth century.

History is not a scientific sermon forsaking human experience and substituting facts or events to it: it integrates the most active and sometimes even the most prolix aspect of human experience, the act of interpretation. Whenever we deal with objectivity in history, we have to remove from our thoughts and practice the romantic idea that there is a truth hidden somewhere and that a thorough research, setting up a strategy of unveiling the mystery and using the most exact sciences, can come to a discovery of truth.

The paradox lies in the fact that objectivity is rather reached when subjectivity is taken into account, and when it is pursued for its own sake. As the meaning of historical facts is forever changing, historical objectivity comprehends, in theory at least, the totality of the rectifications, or the reinterpretations, of the past: it proscribes one simple and unique interpretation and it includes human experience in the whole process. As history is represented in a series of narratives, of interpretations articulating a meaning, every event or period of history is dependant on a plot mediating the materialisation of a strictly human experience of time. And since meaning is implied in a narrative, the various metamorphoses of meaning are displayed in the successive re-interpretations of history between the moment of the occurrence up to present day. History can therefore be conceived as dependant on the metamorphoses of this meaning through traditions and revolutions.

Our subject matter being here the English Reformation, or on a broader scale, Renaissance theology, how can the historian, and more specifically the historian of ideas, deal with it? The status of the events (the separation from Rome, the advent of Protestantism and the situation during the Renaissance in the British Isles) is sometimes put into question as being not fundamental by some thinkers (John Henry Newman for example, given the religious controversies during the Victorian period). Yet, the status of the interpretation of what happened at that time proved historically successful as Britain gradually emerged and owed her 
specificity thanks to the Anglican Schism. Therefore, whenever we try to constitute an interpretation which would, in our eyes, be totally founded, we have to remind ourselves that whatever a Catholic or a Protestant interpretation would agree on is of very little importance and also that a community of synchronic interpretations on a event or a period would not do because they would tend to coincide, eventually; a diachronic display of interpretations is largely to be preferred. Moreover, to have a whole set of different interpretations of the same period or event would perhaps not be worth dealing with, if ever it were desired: we have to take care of interpretations which retain a certain value, and which throw light on the substantial importance of past events at certain periods of time.

As the Christian religion is fundamentaly based on teleological presuppositions, time has a great role to play in discriminating and in focusing on some elements of the doctrine more than others. As the main object of study in the present article is the theology of the via media of Renaissance Anglicans, I have therefore chosen to focus on one interpretation given in the twentieth century and emanating from a distinguished man of letters, to assess the evolution of the translation / interpretation of the Word into words through history.

As Newman suggested, the Christian religion is apt to assert its attractive power through stages of psychological development in the mind of the believer and stages of historical development in the world. The idea of development implies that time favours and also selects the elements of doctrine which are the most to the purpose and the only ones to be taken into account for a true appraisal and assessment of sound theology. If the theologians of the Elizabethan and Caroline via media tried to define a perspective to advocate the Real Presence and to maintain the notion of a fundamental mystery alluding to the meaning of mankind and the quest that has to be pursued, the sanction of history and the innumerable interpretations that have reinstituted the debate up to the present day are necessarily and inexorably led towards a purer and purer understanding of their basic tenets. The diffusion of the doctrine set up by Elizabethan and Caroline Anglicans through the centuries developed ideas which are still upheld, venerated, and sometimes even adapted to our modern world: these are therefore to be considered the most central to the truth they tried to establish. To measure how the teaching of these theologians has developed allows us not only to highlight some of their initial ideas but also to show where their originality is really conspicuous. Every twentieth century perspective on the essentials of Renaissance Anglican theology is sure to capture a fundamental dimension of its thought in its development.

My own way of looking at the event of Anglicanism today shall follow Thomas Stearns Eliot's special view on it, not only because he was awarded the Nobel Prize and the Order of Merit but also because he incarnated the tendencies of his age: that is the first half of our century. Eliot's perspective is not only interesting for reasons attached to the quality of his views (as a poet he was particularly receptive to the floating ideas or the certitudes of our modern world), it is also attached to conditions of thought which were bound to develop in a direction akin to principles held in the Anglican view of the world. 
The true meaning of Christianity for him lay in the Incarnation, which was a historical fact and a principle for him, to be found nowhere better explained and interpreted in the English language but during the Elizabethan period. What is paradoxical is that T.S. Eliot advocated a return to the values of the Renaissance and made of the Elizabethan via media the model theology to be copied and followed today if we wanted to rejuvenate the world, after having ascribed the decadence of our modern age (see The Waste Land), to a dissociation of thought starting precisely in the Renaissance period.

His evaluation of the Anglican theology of the via media proves enlightening in so far as he situated it in time and out of time, as a moment and a process operating the transition from the Middle Ages to the Modern Age and reassuming the true meaning of the Christian religion despite a gradual and inexorable 'Disintegration of the Intellect' ${ }^{1}$. Eliot's reappraisal and refreshment of Hooker, Andrewes and Bramhall enunciated his views on the fundamental importance of the via media and of the Incarnation for Anglicans: he made use of these theologians to oppose their world of light and mediation to the secularized world of darkness and loneliness. If the Meaning was for him the Incarnation, the only tradition he wanted to proclaim was the Christian Tradition symbolized by the Elizabethan via media. But all of this needs some clarification.

T.S. Eliot was attracted to Anglicanism through Lancelot Andrewes, and his own slant on Renaissance Anglicanism bears the importance of this encounter. In an article on Lancelot Andrewes written shortly before his conversion to Anglo-Catholicism, Eliot exposed the major reasons justifying his interest in Renaissance theology.

The cultural atmosphere of the Elizabethan period represented a kind of ideal to him: the Church of England, the via media, were the very spirit of Anglicanism, as they amounted to a sublime intellectual, political and religious achievement. If Eliot went on praising the English Church of the period, comparing it even to the Catholic and Apostolic Church of Dante's time, he also gave the background motives for the picture offered:

A Church is to be judged by its intellectual fruits, by its influence on the sensibility of the most sensitive and on the intellect of the most intelligent, and it must be made real to the eye by monuments of artistic merit ${ }^{2}$.

The most important feature of Anglicanism for him (and here again he showed his perspective as a man of letters) is to be found in the prose of Hooker and Andrewes:

The intellectual achievement and the prose of Hooker and Andrewes came to complete the structure of the English Church as the philosophy of the thirteenth century crowns the Catholic Church (...) If the Church of Elizabeth is worthy of the age of Shakespeare and Jonson, that is because of the works of Hooker and Andrewes ${ }^{3}$.

Three things then are combined to make the Church of England the intellectual and aesthetic equivalent of the Roman Catholic Church: the 
breadth of culture, the prose qualities and the impersonality of thought of her exponents:

Andrewes's emotion is purely contemplative; it is not personal, it is wholly evoked by the object of contemplation, to which it is adequate; his emotions wholly contained in and explained by its objects ${ }^{4}$.

To understand this rather mystifying sentence, one should refer to the Clark Lectures Eliot had given in Cambridge in 1926 (one year before his conversion) which dealt with the question of metaphysical poetry and more largely with the reasons why European culture had known a decadence since the sixteenth century. After the 'dissociation of sensibility' theory he had developed in an article in $1921^{5}$, Eliot wanted to write a series of books going much further into the study of this trend and dealing with what he called then 'the Disintegration of the Intellect'. In metaphysical poetry, Eliot wrote,

(...) the thought is so to speak fused into poetry at a very high temperature...to draw within the orbit of feeling and sense what hed existed only in thought. It creates a unity of feeling (... ${ }^{6}$

This unity of feeling is achieved when thought is in tune with feeling, but this is only possible during periods when sensibility is enlarged ${ }^{7}$, periods which are called 'metaphysical periods', when people are given 'the gift of incarnation' in their writings, when sense is 'elevated for a moment to regions ordinarily attainable only to abstract thought' 8 . Andrewes is one outstanding example of this unity of feeling and Eliot associated him to a tradition of thought he endeavoured to link to the spirit of the Middle Ages, which he thought was the key period of history, when Christianity was united and universality expressed through a common language, Latin. Namely, this tradition goes back to Hugh and Richard of Saint Victor (De Gratia Contemplationis ) who suceeded in writing a prose consisting in 'an intellectual preparation for spiritual contemplation' and not in 'a spiritual haschisch, a drugging of the emotions' ${ }^{9}$, the latter elements being infused in the writings to be found after the Elizabethan period, when this tradition was dissociated. If the trend of this metaphysical thought is to be found in Hugh and Richard of Saint Victor, Thomas Aquinas and Dante, this is a tradition of ontological thought conveying the gift of incarnation, present in Andrewes and reigning supreme during the Elizabethan period.

In fact, T.S. Eliot felt that the shift from ontology to psychology was the most meaningful movement at the beginning of the seventeenth century, and that its practical fulfilment was performed through the CounterReformation movement, inspired by Jesuitism, and also through Protestantism. The problem for Eliot was not between Catholicism and Protestantism but between the passage from ontological thought where philosophy was not separated from theology, to psychological thought present both in Protestantism and Jesuitism: 
(...) the unique character of this century (the seventeenth century) ... [is that] it experienced the acute crisis of the transition from the old to the new Europe (to the Europe, we might say, of 1914) ${ }^{10}$.

The greatest difference between Andrewes and John Donne then lay in this fundamental opposition accounting for the gradual dissociation up to our present age. Andrewes is part of a tradition which goes back to the Greek, through the Church of the Middle Ages, whereas there is something impure in Donne, owing to the influence of Jesuitism on him.

'That Jesuitism is a phenomenon typically of the Renaissance is a fact upon which I insist' 11. Placing Jesuitism outside the classical tradition borne by Greek and Roman traditions, outside the tradition of meditation and contemplation of the Middle Ages, Eliot opposed the military spirit of the Jesuits fighting heresy to the contemplative minds with a view to showing that the spirit of controversy made everybody a theologian in the seventeenth century, exacerbated the theological controversies and entailed a destruction of religion:

Theology which is bent on political controversy, theology at bay, extinguishes the light of pure ideas, the Greek disinterestedness of mind, which the Middle Ages had revived; but it does not extinguish religious sentiment...Religion and theology, abandonning the pursuit of metaphysical truth, develop in the seventeenth century in the direction of psychology ${ }^{12}$.

The tradition of thought based on a search for divine contemplation thanks to reason, on a quest for beatitude through prose and narrative, having Aristotle, Aquinas, Dante and Andrewes as its proponents is strongly opposed to the tradition of thought based on life in the flux of immediate experience, separated from reason. Moreover, the diversion of enquiry and thought entailed an alteration of the human mind so as to adapt it to the new categories of thought; the ideas were drawn not from the objects but from the ideas of these objects (Descartes's sixth meditation) hence the development of individualism, of self-consciousness and of epistemology.

T.S. Eliot's aesthetic and intellectual version of Elizabethan Anglicanism therefore strips the via media of its religious meaning and turns it into a metaphysical principle. His article on Bishop Bramhall ${ }^{13}$ provides an other dimension as well: that of a conception of civilisation and culture which is greatly endangered today. In this article, Eliot went on explaining how the spirit of the Anglicans (and in that respect, Bramhall was presented as very close to Hooker) was different from a trend debilitating the true nature of man. Thomas Hobbes's writings are held responsible for this new tradition, as they are seen as the adumbration of the physical science of atoms, of materialistic determinism, and of totalitarianism. Through the controversy which opposed Bramhall to Hobbes, Eliot wanted to stress the idea that to follow the way of the via media in the twentieth century, presented as a 'period of debility', was becoming an impossible task.

To understand Eliot's view, it is necessary to see in what context he started to be interested in Anglicanism. It was mainly because of a certain 
disillusion with the modern age and its values that he decided to revert to a sphere of thought which would be displaying everything but 'values', that is mere appearances excluding any possibility to find reality in the world. Eliot was looking for a way of life in which thought is not separated from feeling: his attitude is therefore not the result of an epistemological choice even if his explorations towards reality, or an absolute, closely followed the path of the philosopher or the artist ${ }^{14}$. For him, Anglicanism articulated belief with the wisdom accumulated in centuries, associated a tradition to the meaning it vehiculated: a meaning not subject to constant ratiocination but leading to constant contemplation.

The end of The Waste Land had asserted such a search for a unifying principle: it rang like an appeal for the restoration of tradition, so as to set the lands in order ${ }^{15}$. The criticism of decadence had led eliot to look for a renaissance of style and order and to support the view of an ideal to follow which would be close to classicism, that is to say to an authoritarian and superior conception of art and values in general. To his mind, if the modern age was the age of slipshod thought, of the disintegrated intellect, if, in order to renew with this metaphysicality which pertained to the greatest ages of mankind it became necessary to rejuvenate the tradition issued from the Antiquity, it was then essential to come back to the Elizabethan period, when thought and feeling were fused. The Elizabethan Age actualized for Eliot the fabulous and marvellous significance of a combination of feeling, thought, reason and beauty.

In Lancelot Andrewes, Eliot pointed to the idea that to revert to via media Anglicanism would represent, as the prose of Andrewes clearly shows, the possibility to reach the Absolute through words, through discourse: the quest for the Word, which is one feature of his poetics after his conversion, combined with the continuation of the meaning attributed to a tradition already perpetuated by andrewes, and which took the Incarnation to be the key principle.

The tradition linking Eliot to Andrewes and to Christianity at large is a common study and a common glorification of the Incarnation, felt as being the central Meaning not only of their own existence, but also of European civilisation. One poem is emblematic of the importance of Andrewes in that respect. 'Journey of the Magi', an Ariel Poem celebrating the birth of Christ, actually started with a verbatim quotation from one of Andrewes's sermons on the Incarnation of Christ, thus reiterating and adapting to modern times Andrewes's most essential preoccupation, centred on the mystery of the Incarnation. Eliot noted in his article, how often Andrewes had spoken on the Incarnation, and most of Eliot's later writings indicate the very clear relationship he drew between the historical Incarnation and its metaphoric possibilities:

What poetry should do in the theatre is a kind of humble shadow analogy of the Incarnation, whereby the human is taken up into the divine $(\ldots)^{16}$.

The creation of a sensuous embodiment [in poetry] is the making the Word Flesh (...) ${ }^{17}$.

The Christian thinker finds himself inexorably committed to the dogma of the Incarnation (...) ${ }^{18}$. 
I spoke at one point of the culture of a people as an incarnation of its religion; and while I am aware of the temerity of employing such an exalted term, I cannot think of any other term which would convey so well the intention to avoid relation on the one hand and identification on the other ${ }^{19}$.

The Incarnation helped Eliot discover what kind of Christianity he could accept. Through Andrewes, who had drawn Eliot to Anglicanism, the Elizabethan period was given the status of an age which had achieved the fusion of thought and feeling, an analogy and therefore a mataphoric incarnation according to him. The Incarnation is, so to speak, the medium through which the Elizabethan via media is given its real meaning.

T.S. Eliot's views of the Incarnation was the essential element inspiring the the dynamics of his work following his conversion to AngloCatholicism. Through the notion of Incarnation, Eliot tried to articulate a sense, a Meaning giving impetus to his own personal quest for the Word and to an attempt at showing the supernatural vocation of mankind. In his Anglican play Murder in the Cathedral, the Meaning to which Thomas Beckett refered in his sermon (the pattern of action and suffering ${ }^{20}$ ) had the value of a model repeating, as one of the secondary kairoi, the essential Kairos of Christ's passion. But Eliot's kenotic version of the Incarnation ${ }^{21}$ also shifted to an existential conception in so far as it gave a significance to everyday life through a necessary Imitatio Christi. There lies perhaps the essential unity which linked Eliot to Andrewes: Eliot did not only appreciate Andrewes's prose but also adopted the doctrinal content of Andrewes's liturgical conception of time, where the past, the present and the future are mysteriously combined, where everyday experience integrates and recapitulates the true sense of the Incarnation 22 .

It can also be remarked that his idea of a decadence (disintegration, diversion, dissociation, and so on) was just an instance of a general attitude starting towards the middle of the nineteenth century and to which the history of ideas attributes Ernst Cassirer's notion of Kulturkritik. As the word implies, it consists in a critical analysis of Western Culture and qualifies a philosophical and literary genre often giving expression to the Weltschmerz paradigm. This Kulturkritik generally articulated forms illustrating the sense of displacement and opened out on spirituality.

At the crossroads of kenoticism and existentialism and as a representative of the Kulturkritik movement, T.S. Eliot's interpretation of Renaissance Anglicanism is therefore both personal and collective. Personal because in a world in crisis, his life was in crisis, because to become a convert meant for him to live a sacramental life and to be incorporated into the supernatural life, finding out the reasons and the excuse for it in conditions which would favour Anglo-Catholicism. Collective also because his desire for reality in religion had turned him into an Anglican playwright and had made him aware of the fact that his interpretation of Anglicanism could also be favoured by a collective interpretation. Mainly because society as a whole was at stake for him, but also because the necessity for a via media corresponded to his idea of a redemption of the Church of England through a fight against liberalism and 
secularization. Speaking of 'the vital importance of the reunion of Christendom ${ }^{23}$, he remarked that the choice was between the formation of a new Christian culture, and the acceptance of a Pagan one, that the Christian world-order would be victorious and that the ideal Christian society could only be realized through the Church of England.

The renaissance in life he advocated for himself also implied a renaissance of the falling world in which he lived. Christians versus nonChristians: mankind has to be rejuvenated because it is in a Waste Land, because civilisation has to be rebuilt: there lay the importance of a Renaissance for T.S. Eliot. 


\section{${ }^{1}$ Notes}

The Varieties of Metaphysical Poetry, London: Faber and Faber, 1993, p. 41.

${ }^{2}$ T.S. Eliot Selected Prose, London: Faber and Faber, 1975, p. 180.

${ }^{3}$ Ibid.

${ }^{4}$ Ibid., p. 186.

5 'The Metaphysical Poets': 'In the seventeenth century a dissociation of thought set in, from which we have never recovered...' (Selected Essays, London: Faber and Faber, 1951, p. 288.)

${ }^{6}$ The Varieties of Metaphysical Poetry, op.cit., p 50.

${ }^{7}$ Ibid., p. 54.

${ }^{8}$ Ibid., p. 55.

${ }^{9}$ Ibid., p. 106.

${ }^{10}$ Ibid., p. 74.

${ }^{11}$ Ibid., p. 75.

${ }^{12}$ Ibid., p. 78.

13 'John Bramhall' (1927), (Selected Essays, ibid., p. 354.)

${ }^{14}$ It should be mentionned here that T.S. Eliot had written a doctoral dissertation on Francis Herbert Bradley (Knowledge and Experience in the Philosophy of F.H. Bradley, London: Faber and Faber, 1964), the English Idealist philosopher, and was destined to teach philosophy before he decided to become a poet.

15 'Shall I at least set my lands in order?', The Waste Land (The Complete Poems and Plays, London: Faber and Faber, 1969, p. 74.)

16 'The Aims of Poetic Drama', in Adam International Review, November 1949, p. 12.

${ }^{17}$; 'Poetry and Propaganda', in Bookman, February 1930, p. 601.

${ }^{18}$ Selected Essays, op.cit., p. 408.

${ }^{19}$ Notes Towards the Definition of Culture, London: Faber and Faber, 1962, p. 33.

${ }^{20}$ See Murder in the Cathedral, London: Faber and Faber, 1965, pp. 32 \& 55-57.

${ }^{21}$ There is more about this in J.P. Rosaye 'L'Incarnation selon T.S. Eliot', Etudes anglaises, Paris: Didier Erudition, $50^{\mathrm{e}}$ année, $\mathrm{N}^{\circ} 1$, janvier-mars 1997 , pp. 27-39.

${ }^{22}$ See the beginning of Burnt Norton: 'Time present and time past / Are both perhaps present in time future / And time future present in time past. / If all time is eternally present / All time is unredeemable.'(The Complete Poems and Plays, op.cit., p. 171.)

and The Dry Salvages, section V: 'But to apprehend / The point of intersection of the timeless / With time, is an occupation for the Saint' (The Complete Poems and Plays, op.cit., pp.189-190). See also A.M. Allchin The Dynamics of Tradition, London: Darton, Longman and Todd, 1981 and Nicolas Lossky Lancelot Andrewes the Preacher (1555-1626): The Origins of the Mystical Theology of the Church of England (foreword by Michael Ramsey, afterword by A.M. Allchin, translated from the French by Andrew Louth), Oxford: Clarendon Press, 1991.

${ }^{23}$ 'Catholicism and International Order', in Essays Ancient and Modern, London: Faber and Faber, 1936, p. 113. 